\title{
EFFECT OF HEALTH EDUCATION ON MATERNAL KNOWLEDGE AND CHILD NUTRITIONAL STATUS AMONG CHILDREN UNDER THREE YEARS OLD WITH UNDERNUTRITION, IN PASURUAN, EAST JAVA
}

\author{
Fiashriel Lundy \\ School of Health Polytechnics (Poltekkes), Ministry of Health, Malang
}

\begin{abstract}
BACKGROUND: Undernutrition may disturb child growth and development. At acute phase it may threaten child survival and lead to lost generation. This study aimed to determine the effect of health education on the improvement of maternal knowledge and child nutritional status.

SUBJECT AND METHODS: This was a quasi-experiment study, before and after with no control design. A total sample of 75 children under three years old with undernutrition was selected for this study from Posyandu, at Community Health Center (Puskesmas) Gondangwetan, Pasuruan, East Java. The independent variable was health education. The dependent variables were maternal knowledge in nutrition and child nutritional status, as measured by weight for age. Maternal knowledge and confoundding factors were measure by a questionnaire. Child nutritional status was measure a month and two months after health education. The confounding factors included family income and maternal education. The effect of the independent variables on the dependent variables were analyzed using multiple logistic regression model.

RESULTS: Knowledge in nutrition increased significantly before and after health education $(b=7.35 ; \mathrm{p}=0.001)$. A month after health education, children whose mother had high knowledge in nutrition were 2.6 times more likely to have good nutritional status than those whose mother had low knowledge, although it was not statically significant $(\mathrm{OR}=2.57$; $\mathrm{p}=0.195$ ). Two months after health education, children whose mother had high knowledge in nutrition were 2.2 times more likely to have good nutritional status than those whose mother had low knowledge, although it was not statically significant $(\mathrm{OR}=2.21 ; \mathrm{p}=0.147)$. These estimates were made after controlling for the effect of family income. Children whose mother had higher family income were $\mathbf{1 2 . 2}$ times more likely to have good nutritional status than those whose with low family income $(\mathrm{OR}=12.2$; $\mathrm{p}=0.037$ ).
\end{abstract}

CONCLUSION: Health education to mothers can improve knowledge in nutrition and improve nutritional status among children under three years old in Pasuruan, East Java.

Keywords: health education, knowledge, nutritional status, children under three years old 